\title{
Redescription and new records of Synopia ultramarina Dana (Amphipoda: Synopiidae) from off the northeastern Brazil, with comments on its morphological variations
}

\author{
André R. Senna' (1), Luiz F. Andrade' (1), Urssula N. Guedes² (i), Guilherme H. Pereira-Filho³
}

\footnotetext{
1. Universidade do Estado do Rio de Janeiro (UERJ), Faculdade de Formação de Professores (FFP), Departamento de Ciências (DCIEN). Rua Dr. Francisco Portela, 1470, Patronato, 24435-005 São Gonçalo, RJ, Brasil. (senna.carcinologia@gmail.com)

2. Universidade Federal Rural do Rio de Janeiro, Programa de Pós-graduação em Biologia Animal. Decanato de Pesquisa e Pós-Graduação, UFRRJ, Rod. BR-465, Km 7 23890-000 Seropédica, RJ, Brasil.

3. Universidade Federal de São Paulo, Instituto do Mar, Laboratório de Ecologia e Conservação Marinha. Santos, SP, Brasil.
}

Received 23 December 2019

Accepted 27 May 2020

Published 24 July 2020

DOI 10.1590/1678-4766e2020017

\begin{abstract}
Synopia ultramarina Dana, 1853 is considered a circumtropical species and was originally described based on material collected from two localities near halfway between the southwestern Africa and northeastern Brazil. The species is redescribed here with samples from Fernando de Noronha Archipelago, Pernambuco state, northeastern Brazil. The material examined was collected by SCUBA diving, from rhodolith beds, in Ressureta Channel, between Meio and Rata Islands. Additional material was collected from off Ceará state coast, during environmental consultancies, by Petrobras S. A., and off Pernambuco state coast, during the Project REVIZEE NE IV. Discussion on morphological variations of the species is presented, based on the studied material and previous descriptions in the literature.
\end{abstract}

KEYWORDS. Crustacea,oceanic island, new record, taxonomy, Southwestern Atlantic.

RESUMO. Redescrição e novos registros de Synopia ultramarina Dana (Amphipoda: Synopiidae) do nordeste do Brasil, com comentários sobre suas variações morfológicas. Synopia ultramarina Dana, 1853 é considerada uma espécie circumtropical e foi originalmente descrita com material coletado em duas localidades, a meio caminho entre o sudoeste da África e o nordeste do Brasil. A espécie é redescrita aqui com amostras do Arquipélago de Fernando de Noronha, estado de Pernambuco, nordeste do Brasil. O material estudado foi coletado por mergulho autônomo, em camas de rodolitos, no canal Ressureta, entre as ilhas do Meio e Rata. Material adicional foi coletado ao largo da costa do estado do Ceará, durante consultorias ambientais coordenadas pela Petrobras S. A., e ao largo da costa do estado de Pernambuco, durante o Projeto REVIZEE NE IV. É apresentada discussão sobre as variações morfológicas da espécie, baseada no material estudado e em descrições prévias na literatura.

PALAVRAS-CHAVE. Crustacea, ilha oceânica, novo registro, taxonomia, Atlântico Sudoeste.

Synopiidae Dana, 1853 is a cosmopolitan family commonly found in deep sea and, less often, in shallow waters (BARNARD, 1972). According to BARNARD (1969), "the characters of this family are so subtle that they are practically indefinable, yet taxonomists have little trouble in recognizing a synopiid”. However, LöRz \& COLEMAN (2013) diagnose the family emended after RUFFo (1993), being characterized mainly by presenting head with strong recurved rostrum, galeate or with plough-shaped protuberance, pereonites sometimes with sternal hooks in males, urosomites free, antennae 1 and 2 well developed, accessory flagellum present, coxae 1-3 long, narrow or distally expanded, gnathopods simple or subchelate, linear, carpus elongated, uropods 1-3 biramous, lanceolate, and telson very long (except in Synopia Dana, 1852), entire or incised.

There are currently 108 known species of Synopiidae, grouped in 17 genera around the world (HORTON et al., 2020 onwards). Five species are recorded from Brazilian waters: Metatiron tropakis (Barnard, 1972); Pseudotiron longicaudatus Pirlot, 1934; Synopia ultramarina Dana, 1853; Syrrhoe crenulata Goës, 1866; and Tiron biocellata Barnard, 1962 (SEREJo \& SiqueIra, 2018). One of them, S. ultramarina, considered a circumtropical species (BoLTovskoy, 1999), was described by Dana with material collected from two localities near halfway between the southwestern Africa and northeastern Brazil $\left(8^{\circ}-12^{\circ} \mathrm{S}, 11^{\circ}-14^{\circ} \mathrm{W}\right.$; and $4^{\circ}-7^{\circ} \mathrm{S}$, $21^{\circ}-25^{\circ} \mathrm{W}$ ). Despite that, Hughes (2009) identified the type locality as Tropical Western Atlantic, information reiterated by SEREJO \& SiqueIra (2018). The latest authors also pointed out that Dana would have registered $S$. ultramarina from the coast of the Brazilian state of Espírito Santo. In fact, the record from the coast of Espírito Santo was done by WAKABARA et al.(1991), in the latitude range $18^{\circ} 33^{\prime}-19^{\circ} 50^{\prime} \mathrm{S}$, without longitude data. After that, another record of this species for Brazilian waters was made by Young \& SEREJO (2005), with material from the Abrolhos Bank. 
According to Boltovskoy (1999), the species in the genus Synopia are epipelagic, "practically hypo-neustonic", bathymetrically distributed from 0 to $50 \mathrm{~m}$ deep. However, there are records of S. ultramarina reaching up to $3,000 \mathrm{~m}$ deep (SCHELLENBERG, 1926). Although it has been recorded from several parts of the world, with many morphological variations, the type material is considered probably lost (Serejo \& Siqueira, 2018), which makes taxonomic resolutions difficult. Additionally, some studies that have presented descriptions for this species around the world, have shown morphological variations, mainly related to the mandibles and the telson (DANA, 1853; Bovallius, 1886; SCHELlENBERG, 1926; SHOEMAKER, 1945; LEDOYER, 1986; HiRAYAMA, 1988; BarNARD \& ThOMAs, 1989; Hughes, 2009).

In this paper, we redescribe $S$. ultramarina, with new records from Northeastern Brazil and discuss the morphological variations between the analyzed specimens and the descriptions of other specimens found in the literature. Studied samples come from three localities: off the coast of Ceará and Pernambuco states and Fernando de Noronha Archipelago.

\section{MATERIAL AND METHODS}

The material examined was collected by scuba diving from rodolith beds in Ressureta Channel (Fig. 1), between Meio and Rata Islands, at the Fernando de Noronha Archipelago, Pernambuco state, Brazil (034' $2.51^{\prime \prime S}$, $32^{\circ} 23^{\prime} 34.10^{\prime \prime} \mathrm{W}$ ). The Fernando de Noronha Archipelago includes 21 islands located about $350 \mathrm{~km}$ from off the Brazilian northeastern coast. Samples were collected using a bag with $0.5 \mathrm{~mm}$ mesh, at a depth of 12 meters. Additional material was also collected from off Ceará state coast, by van Veen grab, during environmental consultancies coordinated by Petrobras S. A. (Brazilian Oil Company), and off Pernambuco state coast, by rectangular dredges, during the Project REVIZEE NE IV, as part of the REVIZEE Program (Avaliação do Potencial Sustentável de Recursos Vivos na Zona Econômica Exclusiva Brasileira/Petrobras). All specimens were stored in vials containing $70 \%$ ethanol and are housed at the Crustacea Collections of Universidade do Estado do Rio de Janeiro (UERJ), Museu de Zoologia da Universidade Federal da Bahia (UFBA) and Museu de Oceanografia Prof. Petrônio Alves Coelho, Universidade Federal de Pernambuco (MOUFPE). Appendages and mouthparts were dissected and mounted on glass slides with glycerol gelatin. Drawings were made under optic microscopy (Motic BA-310) with camera lucida, and digitally prepared with CorelDraw 2018. The setal/spine classification adopted in this paper follows GARM \& WATLING (2013). Nomenclature of gnathopod palm is based on Poore \& LOWRY (1997). Distributional map was prepared with QGIS 3.2.1.

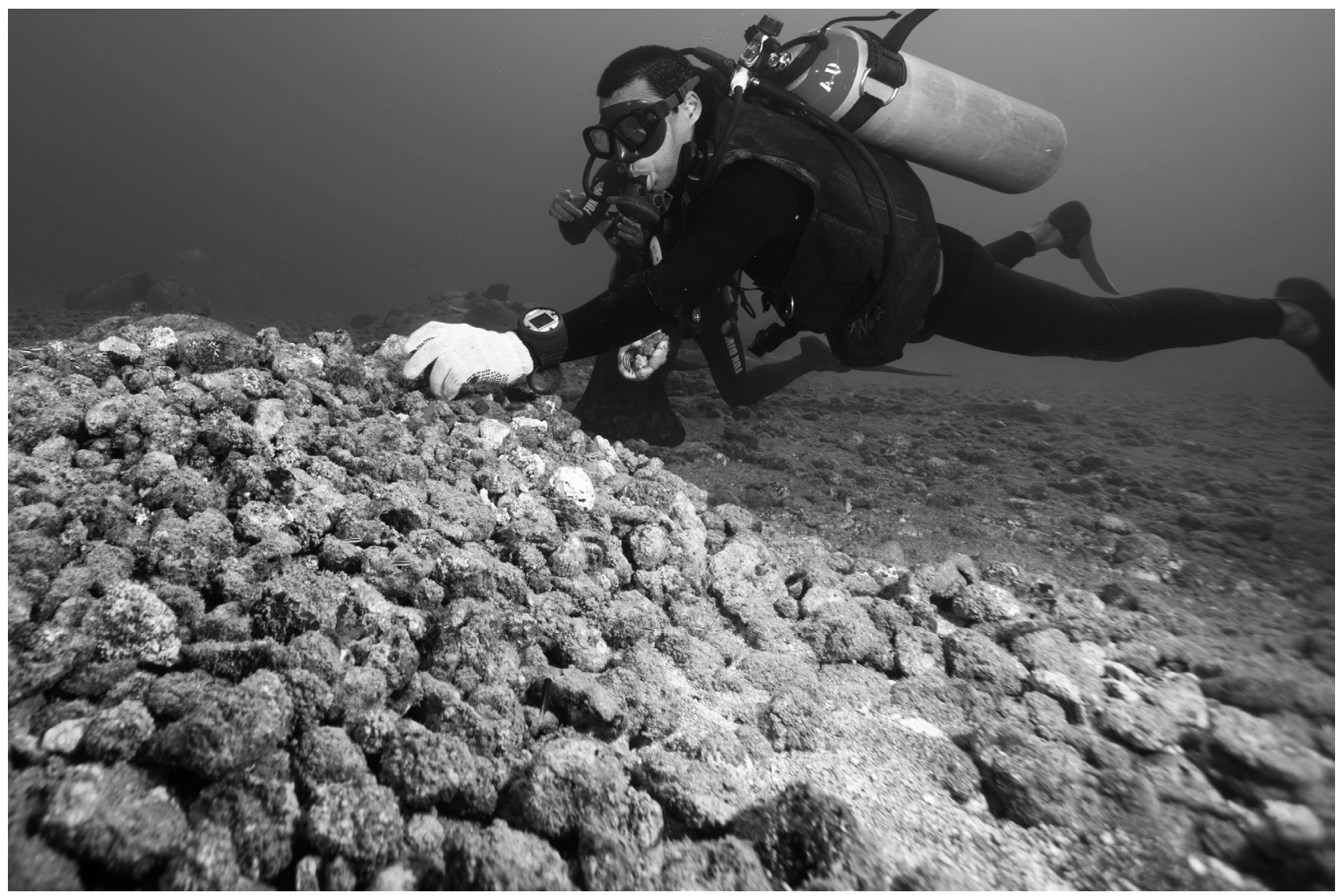

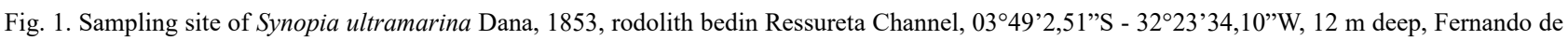
Noronha Archipelago, Brazil. Photo by Zaira Matheus/All Angle. 


\section{RESULTS}

\section{Family Synopiidae Dana, 1853 Genus Synopia Dana, 1852}

Composition of the genus. The genus groups six species: S. angustifrons Dana, 1853; S. caraibica Bovallius, 1886; S. gracilis Dana, 1853; S. orientalis Kossmann, 1880; S. scheeleana Bovallius, 1886; and S. ultramarina Dana, 1853.

\section{Synopia ultramarina Dana, 1853}

(Figs 2-29)

Material examined. 1울 dissected and drawn, September 2012, Fernando de Noronha Archipelago, Pernambuco state, Brazil, 0349'2.51'S, 32²3'34.10”W, 12 $\mathrm{m}$ deep, rhodolith beds (UERJ 542); 1 \%, in $70 \%$ ethanol, same sampling data (UFBA 2288); 1 \% , dissected, same sampling data (UFBA 2289); 1 , , in 70\% ethanol, same sampling data (UFBA 2292); 1 , dissected and drawn, 1 January 2001, Petrobras 1 PEP 1 500J (2), Ceará state, Brazil, 0307'53.2”S, 38 49'26.2”'W, $36 \mathrm{~m}$ deep, soft bottom (MOUFPE 19642); 19 , dissected and drawn, 1 December 2000, REVIZEE NE IV \#165, 6th campaign, Pernambuco state, Brazil, $8^{\circ} 08^{\prime} 06^{\prime}$ 'S, $34^{\circ} 38^{\prime} 7.08^{\prime \prime} \mathrm{W}$, without depth data, bottom of bioclastic sand with granules and gravel (MOUFPE 14566).
Diagnosis. Head protuberant with anterior keel. Accessory eye with 2-3 ommatidia. Antenna 1, primary flagellum, article 1 callynophorate, remaining articles scarcely setose. Mandible palp, article 2 very stout, medial margin with row of setules and 1 long pappose seta. Right lacinia mobilis apically bifid. Left lacinia mobilis with 4 apical teeth. Maxilla 1 inner plate distally rounded. Maxilla 2 inner plate rounded, with medial row of long setae. Pereopods 5-6, basis with posteroventral corner rounded. Uropods 1-2, rami, margins setulose. Telson longer than wide, laterally smooth, with a slight acclivity or laterally serrate.

Description. Based on females, UERJ 542 and MOUFPE 19642 (Fig. 2). Head (Fig. 3) protuberant with anterior keel; rostrum short; accessory eyes with 2 ommatidia. Antenna 1 (Fig. 4), peduncular article 1, anterior and posterior margins with 1 distal short seta each; article 2 anterior margin with 1 short seta distally, posterior margin with 2 short setae distally; article 3 naked; accessory flagellum 2-articulate; primary flagellum 5 -articulate, article 1 with 8 callynophore. Antenna 2 (Fig. 5), peduncular article 3 anterior margin produced distally with a short seta, posterior margin with 1 medial short seta; articles $4-5$ weakly setose with few short setae; flagellum 9-articulate. Upper lip (Fig. 7) rounded, apical margin with a small notch, setose. Right mandible (Fig. 11), molar strongly triturative and with a group of setules basally, incisor with 4 teeth, lacinia mobilis apically bifid,

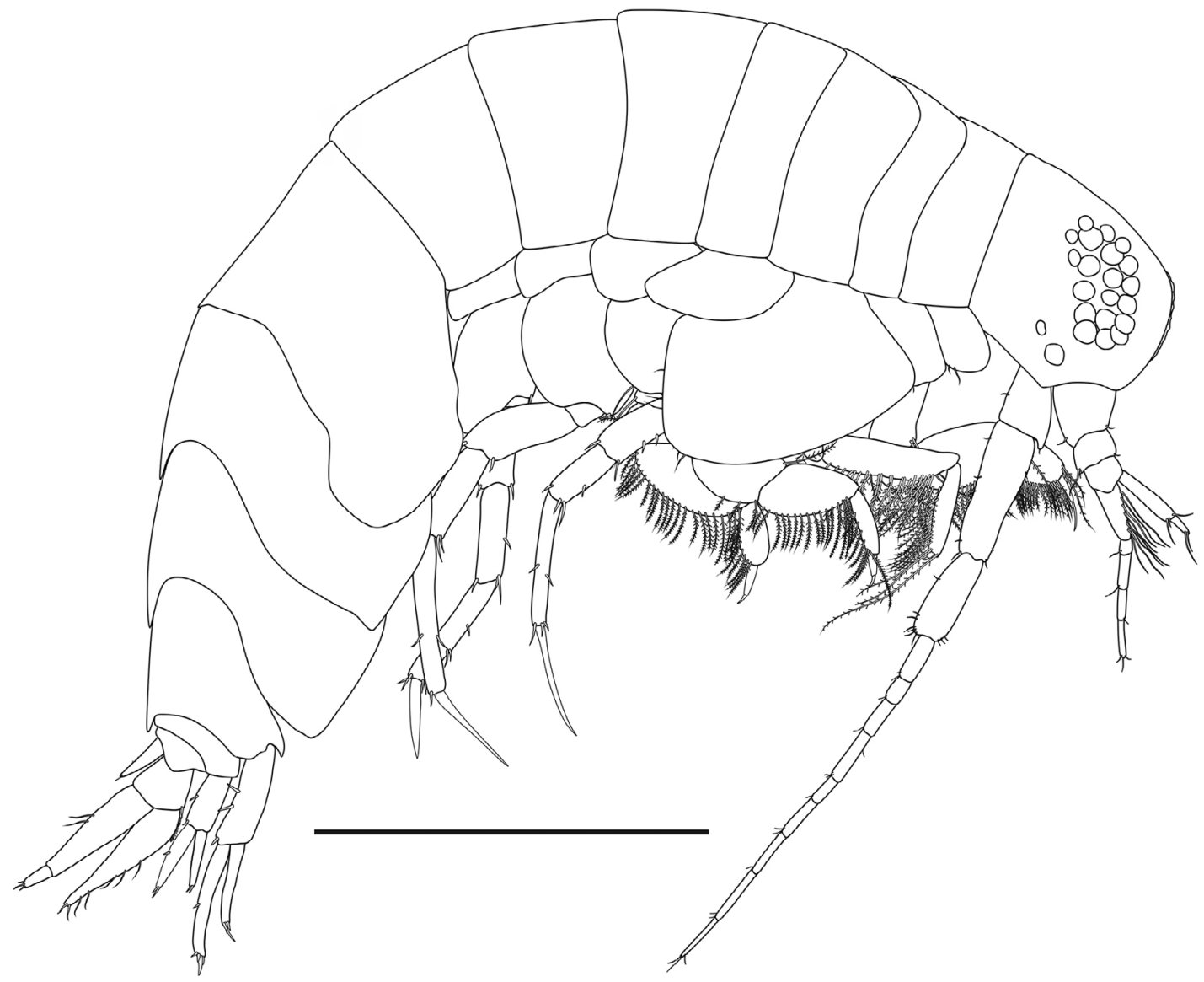

Fig. 2. Synopia ultramarina Dana, 1853, habitus (MOUFPE 19642). Scale bar: $1.0 \mathrm{~mm}$. 
accessory setal row with 2 multicuspidate and 2 apically bifid setae; palp (Fig. 13) 3-articulate, article 1 short and subtriangular; article 2 very stout, about twice longer than wide, medial margin with row of setules and 1 pappose seta subdistally; article 3 very short, with 2 apical pappose setae. Left mandible (Fig. 10), lacinia mobilis with 4 teeth. Lower lip (Fig. 6), outer lobe laterally and apically setose, inner lobe apically setose. Maxilla 1 (Fig. 8), inner plate with 3 long medial pappose setae and 1 short apical seta; outer plate medial margin with row of setules, apically with 6 stout setae; palp 2-articulate, article 2 lateral margin with row of long setules, apically with 4 multicuspidate stout setae and 2 short simple setae. Maxilla 2 (Fig. 9), inner plate with distal field of setules, facial row of long setae present, medial and apical margins with row of long setae. Maxilliped (Fig. 12), inner plate about $0.4 \times$ the length of
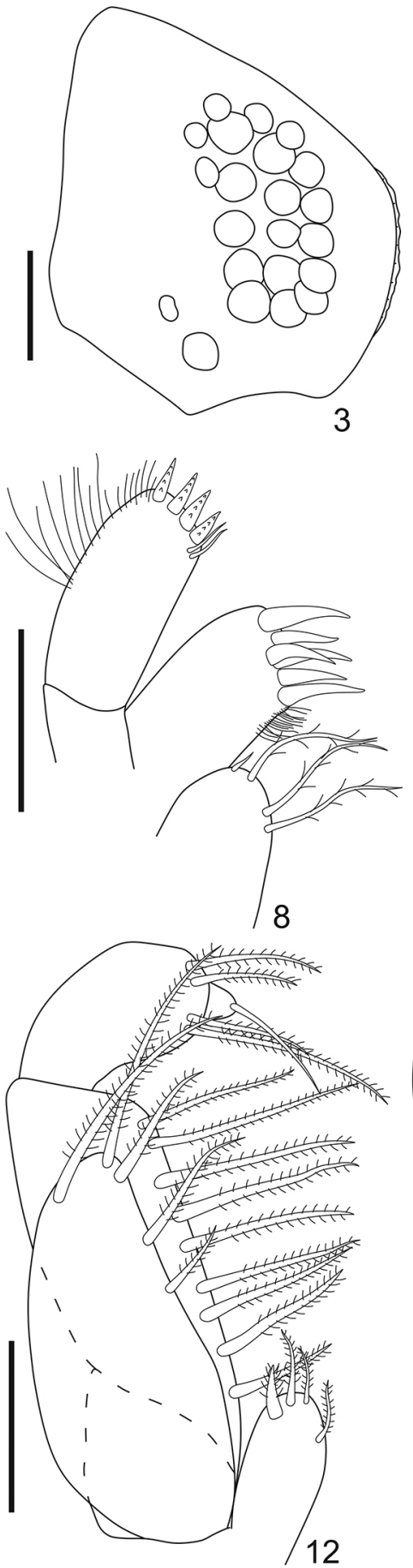
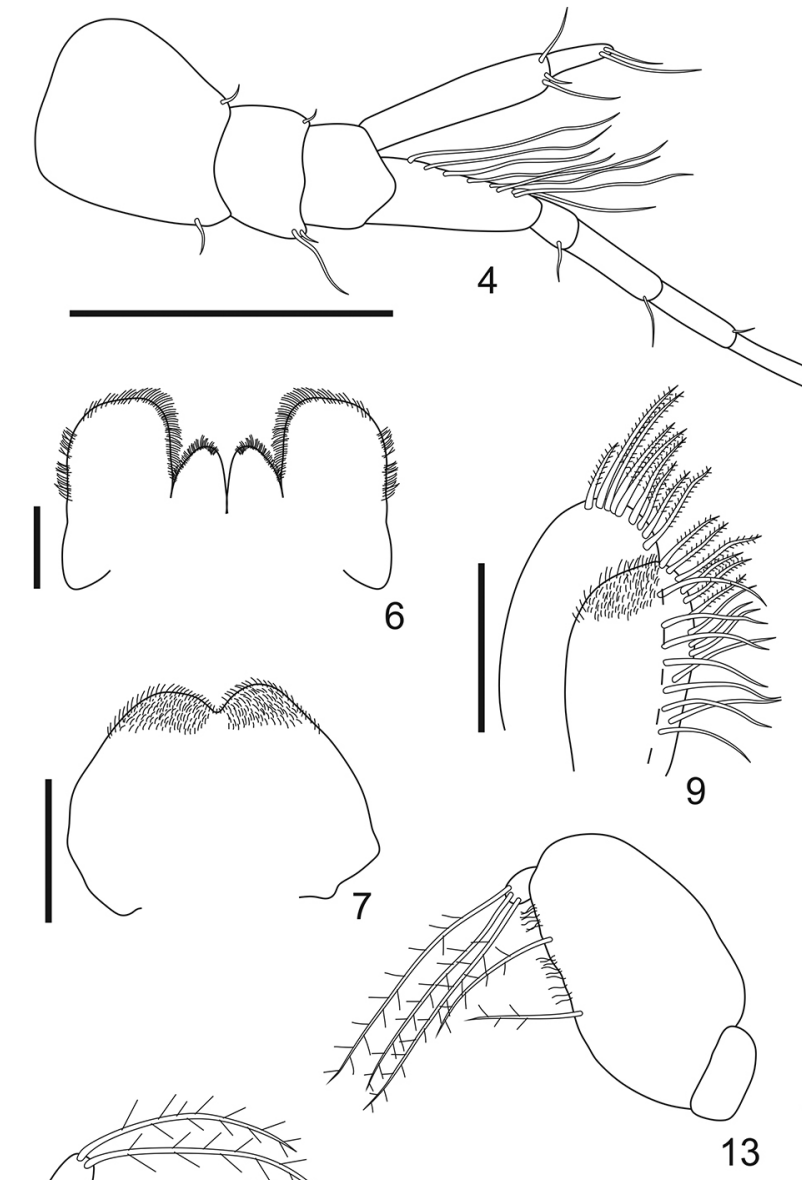

13
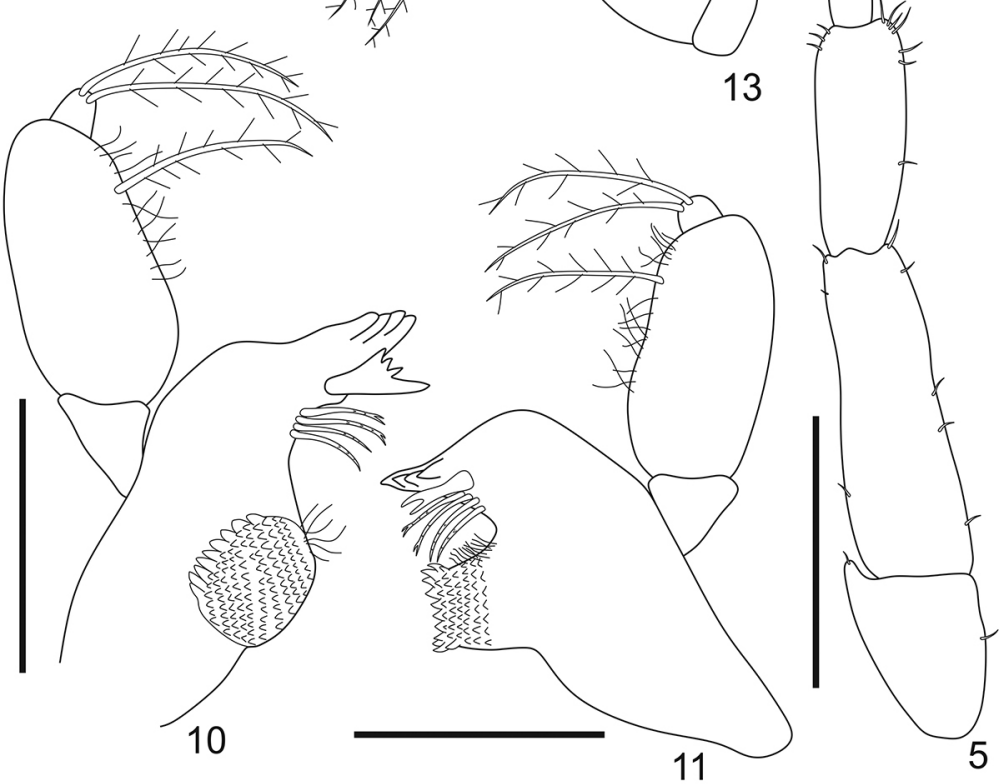

Figs. 3-13. Synopia ultramarina Dana, 1853: 3, head; 4, 5, antennae 1-2; 6, lower lip; 7, upper lip; 8, 9, maxillae 1-2; 10, 11, left and right mandibles; 12, maxilliped (UERJ 542); 13, palp of mandible (MOUFPE 19642). Scale bars: $0.2 \mathrm{~mm}$ for Figs 4, 5; $0.1 \mathrm{~mm}$ for the remains. 

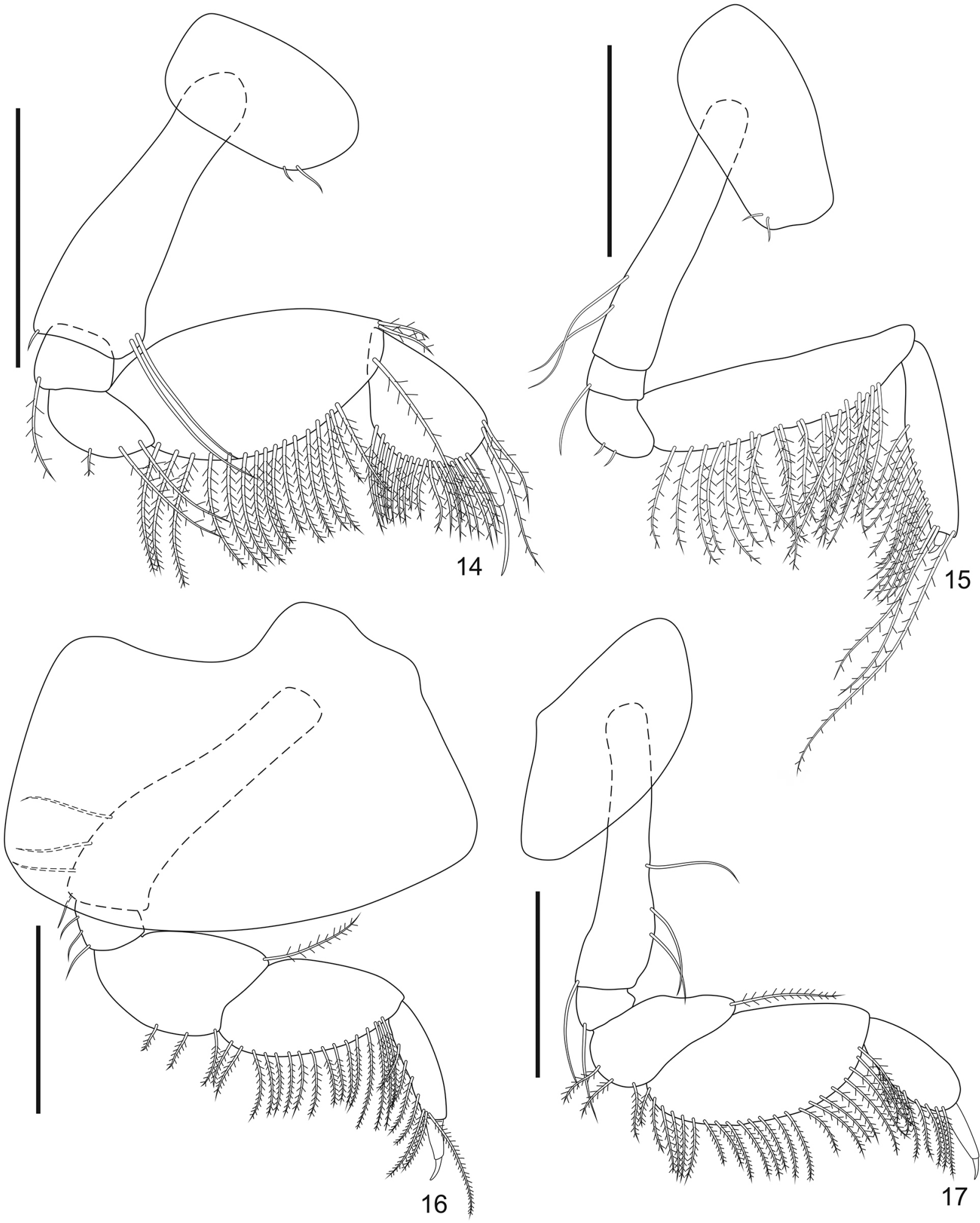

Figs. 14-17. Synopia ultramarina Dana, 1853: 14, 15, gnathopods 1-2; 16, 17, pereopods 3-4 (MOUFPE 19642). Scale bars: $0.3 \mathrm{~mm}$.

outer plate, medial margin with 1 plumose seta, apically with 2 slender and 1 stout plumose seta; outer plate about $0.8 \times$ the length of palp articles 1 and 2 combined, medial margin with 3 plumose setae, apical and lateral margins with 1 long plumose seta each; palp 4-articulate, article 2 with a row of 9 long plumose setae on the medial margin; article 3 with two pairs of subapical plumose setae; article 4 short, bearing a long apical slender seta.

Pereon. Gnathopod 1 (Fig. 14) simple; coxa short, about $0.7 \times$ the length of coxa 2 , with 2 posterodistal short 


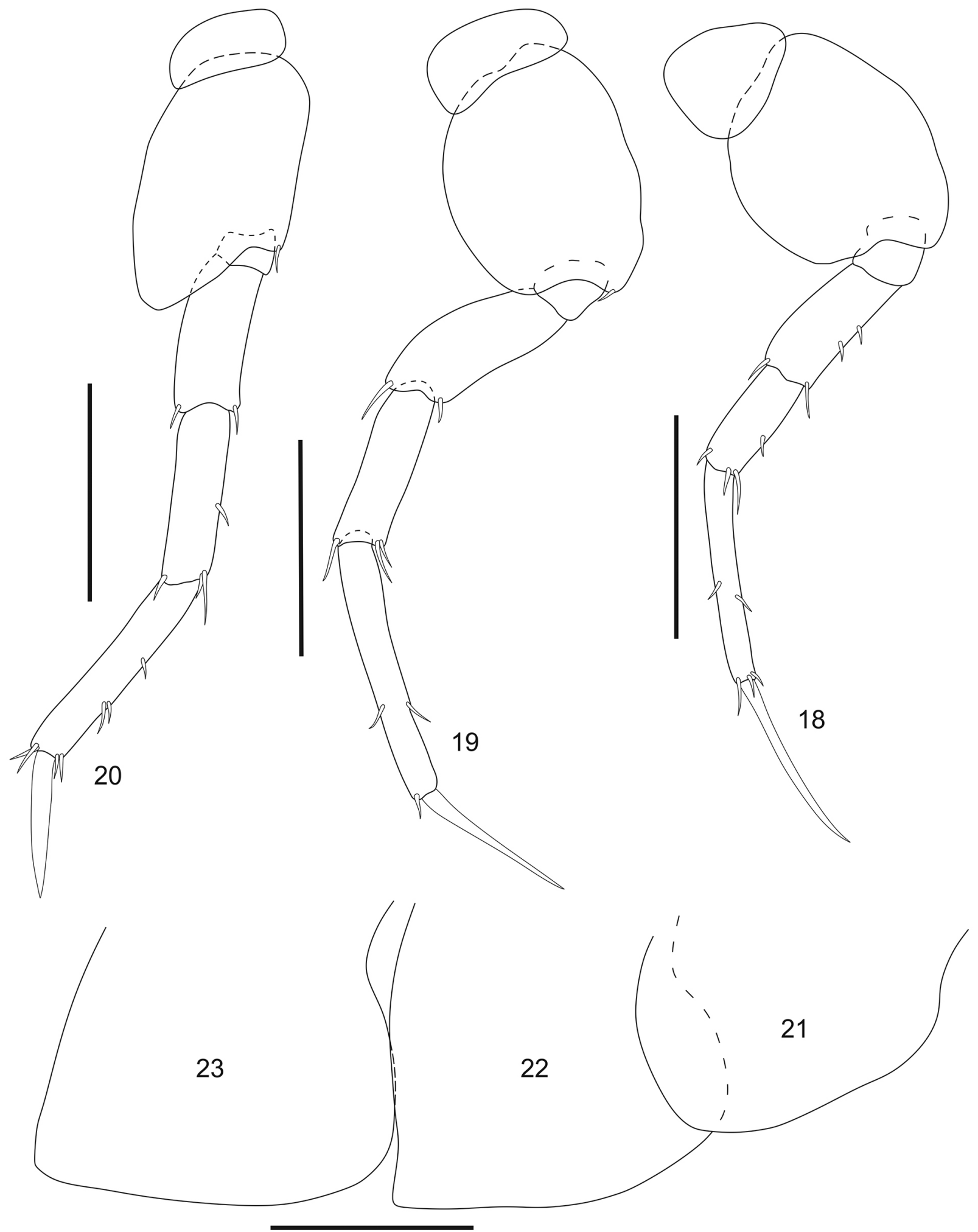

Figs. 18-23. Synopia ultramarina Dana, 1853: 18-20, pereopods 5-7; 21-23, epimeral plates 1-3 (UERJ 542). Scale bars: $0.2 \mathrm{~mm}$.

setae; basis about $3.5 \times$ longer than wide, anterior margin with 2 long setae on a distal lobe, posterodistal corner with $1 \mathrm{seta}$; ischium short and subquadrate, posterodistal corner with 1 long pappose seta; merus posterior margin with 3 pappose setae; carpus twice longer than wide, anterior margin with 2 long pappose setae distally, posterior margin setose, with a row of long plumose setae; propodus ovate, about $1.6 \times$ longer than wide, anterior margin with 2 pappose setae 

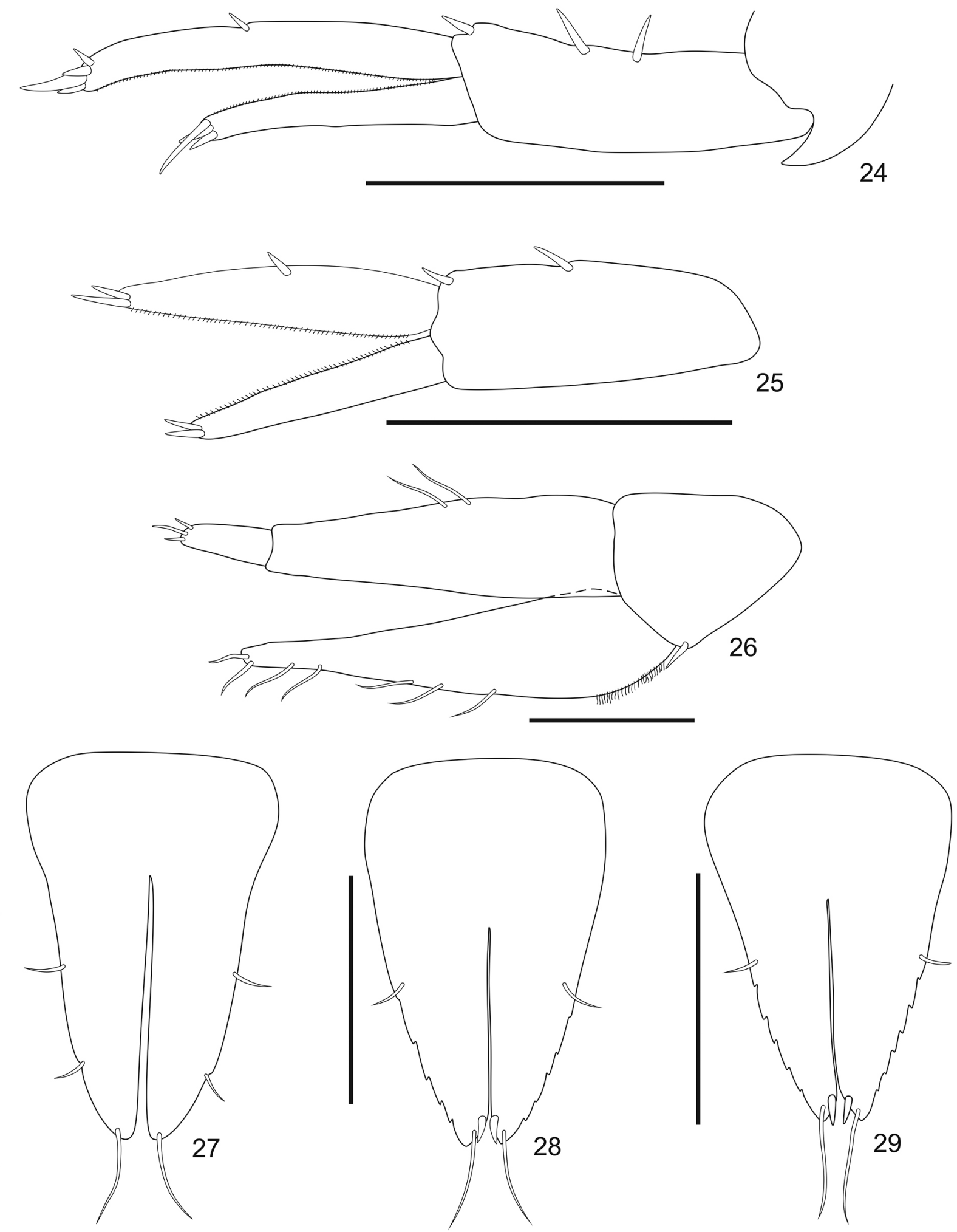

Figs. 24-29. Synopia ultramarina Dana, 1853: 24-26, uropods 1-3; 28, telson (MOUFPE 19642); 27, telson (UERJ 542); 29, telson (MOUFPE 14566). Scale bars: $0.3 \mathrm{~mm}$ for Figs 24, 25; 0.1 for Fig. 27; $0.2 \mathrm{~mm}$ for the remains.

distally, posterior margin setose with row of long plumose setae; palm acute; dactylus about $80 \%$ the length of propodus, nail elongate. Gnathopod 2 (Fig. 15) simple; coxa small, postero ventral margin with 2 setae; basis about $5.2 \times$ longer than wide, posterior margin with 2 long setae; ischium short and subrectangular, posterodistal corner with 1 seta; merus posterior margin with 2 short setae; carpus $3.8 \times$ longer than wide, posterior margin setose, with a row of long pappose 
setae; propodus $4.7 \times$ longer than wide, anterior margin with 1 long pappose seta distally, posterior margin setose, with a row of long pappose setae plus 2 longer pappose setae distally; dactylus vestigial, nail present. Pereopod 3 (Fig. 16), coxa with posterior lobe subquadrate and produced, posterodorsal margin excavate, ventral margin convex; basis $4.2 \times$ longer than wide, posterior margin with 3 setae, posteroventral corner with 1 seta; ischium short and subrectangular, posterior margin with 3 setae; merus $1.5 \times$ longer than wide, anterior margin with 1 long plumose seta distally, posterior margin with 3 plumose setae; carpus $1.9 \times$ longer than wide, posterior margin setose, with a row of plumose setae; propodus posterior margin setose, with a row of plumose setae plus 1 longer plumose seta distally; dactylus about $50 \%$ the length of propodus, nail present. Pereopod 4 (Fig. 17), coxa subtriangular, postero distal lobe produced; basis $4.5 \times$ longer than wide, anterior margin with 3 long setae, posterodistal corner with 1 long seta; ischium short and subrectangular, posterodistal corner with 1 seta; merus $2.2 \times$ longer than wide, anterodistal margin produced, with 1 long plumose seta, posterior margin with 3 plumose setae; carpus twice longer than wide, posterior margin setose with a row of plumose setae;propodus $2.2 \times$ longer than wide, posterior margin setose, with a row of plumose setae; dactylus about $60 \%$ the length of propodus, nail present. Pereopod 5 (Fig. 18), coxa subtriangular and smooth; basis $1.2 \times$ longer than wide, suboval, posteroventral corner rounded; ischium short and subquadrate; merus anterior margin with 2 medial and 1 distal stout seta, posterior margin with 1 stout seta distally; carpus anterior margin with 1 medial and 2 distal stout setae, posterior margin with 1 stout seta distally; propodus $8.7 \times$ longer than wide, anterior margin with 1 medial and 2 distal stout setae, posterior margin with 1 medial and 1 distal stout seta; dactylus elongate, about $90 \%$ the length of propodus. Pereopod 6 (Fig. 19), coxa subrectangular, posteroventral lobe weakly produced; basis $1.4 \times$ longer than wide, suboval, posteroventral corner rounded; ischium short and subrectangular; merus anterior and posterior margins with 1 stout seta distally; carpus anterior margin with 1 stout seta distally, posterior margin with 2 stout setae distally; propodus $8.4 \times$ longer than wide, anterior margin with 1 medial and 1 distal stout seta, posterior margin with 1 medial stout seta; dactylus elongate, about $60 \%$ the length of propodus. Pereopod 7 (Fig. 20), coxa subrectangular, posteroventral corner weakly produced; basis $1.8 \times$ longer than wide, anterodistal corner with 1 short seta, posterodistal lobe well developed, subacute, almost reaching half of merus; ischium short and subrectangular; merus anterior and posterior margins with 1 stout seta distally; carpus, anterior margin with 1 medial and 2 distal stout setae, posterior margin with 1 distal stout seta; propodus $6 \times$ longer than wide, anterior margin with 3 medial and 2 distal stout setae, posterior margin with 2 distal stout setae; dactylus stout, about $60 \%$ the length of propodus.

Pleon. Epimeral plate 1 (Fig. 21), anterior margin slightly concave, ventral margin naked, posteroventral corner rounded, posterior margin convex. Epimeral plate
2 (Fig. 22), anterior margin convex, ventral margin naked, posteroventral corner slightly produced into a subacute angle; Epimeral plate 3 (Fig. 23), anterior margin convex, ventral margin naked, posteroventral corner subquadrate, posterior margin almost straight. Urosomite 1, anterodistal margin produced intoan acute tooth, with a weak sinuosity above. Uropod 1 (Fig. 24), peduncle $3.3 \times$ longer than wide,dorsal margin with 2 stout setae medially and 1 apically; outer ramus dorsolaterally setulose, apical margin with 3 stout setae; inner ramus $1.4 \times$ longer than outer ramus, ventrolaterally setulose, dorsal margin with 1 stout seta medially and 4 apically. Uropod 2 (Fig. 25), peduncle 2.6× longer than wide, dorsal margin with 1 stout seta medially and 1 apically; outer ramus slightly shorter than inner, dorsolaterally setulose, apical margin with 2 stout setae; inner ramus $1.2 \times$ longer than outer, ventrolaterally setulose, dorsal margin with 1 stout seta, bearing 2 setae apically. Uropod 3 (Fig. 26), peduncle short, slightly longer than wide, ventroapical margin with 1 stout seta; outer ramus slightly longer than inner, 2-articulate, article 1 with 2 setae dorsolaterally, article 2 about $30 \%$ the length of article 1, apical margin with 3 setae; inner ramus, ventrolateral margin with a proximal row of setules and 5 setae, apical margin with 2 setae. Telson (Figs. 27-29) 1.6× longer than wide, about $70 \%$ cleft, longer than peduncle of uropod 3, each lobe with 2 lateral setae, distalmost placed on a slight acclivity, and one long apical seta.

\section{DISCUSSION}

Synopia ultramarina is the only species of the genus recorded for Brazilian waters. It is currently considered a circumtropical species (BoLTovsKoy, 1999) and, as stated by us, presents some variations in the past literature among many individuals regarding especially to mouthparts and the lateral margin of telson. With exception of two records from the Pacific Ocean (Hirayama, 1988; Hughes, 2009) and one record from the Indian Ocean (LEDOYER, 1986), all the other records presented here are from the Atlantic Ocean, with bathymetrical range from 0 to $219 \mathrm{~m}$ deep, plus one extralimital record to 3,000 $\mathrm{m}$ deep (Fig. 30; Tab. I). It is worth mentioning that two works discussed herein, Bovallius (1886) and Boltovskoy (1999), were omitted from the distributional map, as the authors mentioned the species distribution as Tropical Atlantic, without geographic coordinates, nor any specific location. Bovallius (1886) cites that he found six specimens of S. ultramarina when analyzing the Captain George von Schéele's pelagic Crustaceans collection, carried out around the world on board the Swedish vessel Monarch. Location and depth information is not provided. In the Habitat section, the author only mentions "Tropical parts of the Atlantic" and in brackets includes the acronyms of the Collections of the Royal Swedish State Museum of Stockholm and the Zoological Museum of the University at Upsala. On the other hand, BoLTovsKoy (1999) presents an identification key to species of Synopia and a diagnosis for $S$. ultramarina, but the illustrations of this species were modified after Bovallius (1886). 


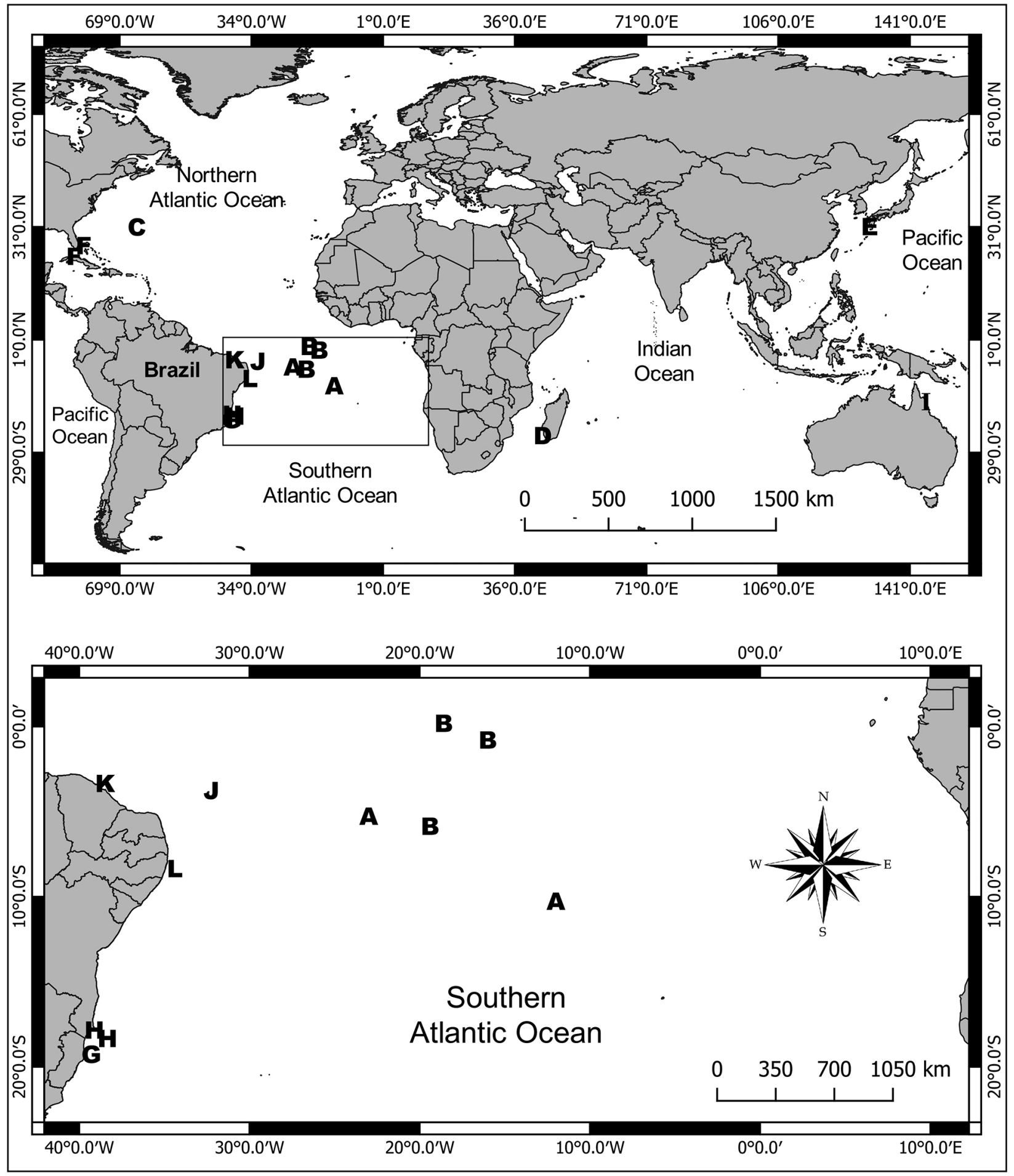

Fig. 30. Distribution of Synopia ultramarina Dana, 1853: A, Tropical Atlantic (DANA,1853); B, Tropical Atlantic (SchelLENBERG, 1926); C, Bermuda (Shoemaker, 1945); D, Tulear Reef, South Madagascar (Ledoyer, 1986); E, Tomioka Bay, Japan (HiRayama, 1988); F, Florida Keys and Grand Bahama Island (Barnard \& Tomas, 1989); G, Espírito Santo state coast, Brazil (WaKabara et al., 1991); H, Coroa Vermelha, Abrolhos Bank, and California Reef, Parcel of Abrolhos, Bahia state, Brazil (Young \& Serejo, 2005); I, Lizard Island, Australia (Hughes, 2009); J, Fernando de Noronha Archipelago (current study); K, off Ceará State coast (current study); L, off Pernambuco State coast (current study).

Regarding the mandibular palp, there are different patterns of number and distribution of elongate setae. In the original Dana's description, palp bears two simple setae in the inner margin of the article 2 and two other apical simple setae in the article 3 . The specimen described by BovalLius
(1886) presents one plumose seta in the inner margin of the second article and two apical plumose setae in the third. In LEDOYER (1986) and DANA (1853) the pattern of setae is the same. HIRAYAMA (1988) illustrated the mandibular palp with two plumose setae in the inner margin, but these placed 
Tab. I. Occurrences of Synopia ultramarina Dana, 1853 worldwide: Letters A-L, records indicated on map (Fig. 30); $\mathrm{x}^{1-2}$, records omitted on map; *estimated coordinates; ${ }^{*}$ without longitude data; ${ }^{+}$J. F. Souza-Filho (pers. comm.).

\begin{tabular}{|c|c|c|c|c|c|}
\hline Occurrences & Coordinates & Depth & Locality & Sampling/habitat & Reference \\
\hline \multirow{2}{*}{ A } & $08^{\circ}-12^{\circ} \mathrm{S}, 11^{\circ}-14^{\circ} \mathrm{W}$ & --- & Tropical Atlantic & --- & DANA (1853) \\
\hline & $04^{\circ}-07^{\circ} \mathrm{S}, 21^{\circ}-25^{\circ} \mathrm{W}$ & --- & Tropical Atlantic & --- & \\
\hline \multirow{3}{*}{ B } & $05^{\circ} 59^{\prime} \mathrm{S}, 17^{\circ} 39^{\prime} \mathrm{W}$ & $0 \mathrm{~m}$ & Tropical Atlantic & Trawl at night & SCHELLENBERG (1926) \\
\hline & $0^{\circ} 52^{\prime} \mathrm{S}, 16^{\circ} 00^{\prime} \mathrm{W}$ & $0 \mathrm{~m}$ & Tropical Atlantic & Trawl at night & \\
\hline & $0^{\circ} 46^{\prime} \mathrm{N}, 18^{\circ} 59^{\prime} \mathrm{W}$ & $0-3000 \mathrm{~m}$ & Tropical Atlantic & --- & \\
\hline $\mathrm{C}$ & $32^{\circ} 12^{\prime} \mathrm{N}, 64^{\circ} 36^{\prime} \mathrm{W}$ & $0 \mathrm{~m}$ & $\begin{array}{l}\text { Bermuda, } 9 \text { miles SE off } \\
\text { Nonsuch Island }\end{array}$ & --- & SHOEMAKER (1945) \\
\hline $\mathrm{D}$ & $23^{\circ} 25^{\prime} \mathrm{S}, 43^{\circ} 39^{\prime} \mathrm{E}^{*}$ & $0-15 \mathrm{~m}$ & Tulear Reef, South Madagascar & $\begin{array}{l}\text { Trawl and bottom } \\
\text { samples }\end{array}$ & LEDOYER (1986) \\
\hline $\mathrm{E}$ & $32^{\circ} 32^{\prime} \mathrm{N}, 130^{\circ} 3^{\prime} \mathrm{E} *$ & --- & Tomioka Bay, Japan & --- & HIRAYAMA (1988) \\
\hline \multirow[t]{2}{*}{$\mathrm{F}$} & $24^{\circ} 41^{\prime} \mathrm{N}, 81^{\circ} 11^{\prime} \mathrm{W} *$ & $7 \mathrm{~m}$ & Florida Keys, USA & $\begin{array}{l}\text { Trawl at night, bottom } \\
\text { of sand }\end{array}$ & $\begin{array}{c}\text { BARNARD \& THOMAS } \\
\text { (1989) }\end{array}$ \\
\hline & $27^{\circ} 26^{\prime} \mathrm{N}, 78^{\circ} 57^{\prime} \mathrm{W} *$ & $219 \mathrm{~m}$ & Grand Bahama Island, USA & Trawl at night & \\
\hline G & $18^{\circ} 33^{\prime}-19^{\circ} 50^{\prime} \mathrm{S} * *$ & $41-60 \mathrm{~m}$ & Espírito Santo state coast, Brazil & Bottom of muddy sand & WAKABARA et al. (1991) \\
\hline \multirow{2}{*}{$\mathrm{H}$} & $\begin{array}{l}17^{\circ} 57^{\prime} 40.0 ” \mathrm{~S} \\
39^{\circ} 12^{\prime} 50.5^{\prime \prime} \mathrm{W}\end{array}$ & --- & $\begin{array}{c}\text { CoroaVermelha Lagoon, } \\
\text { Abrolhos }\end{array}$ & Soft bottom samples & Young \& SEREJo (2005) \\
\hline & $\begin{array}{c}18^{\circ} 6^{\prime} 7.8^{\prime \prime} \mathrm{S} \\
38^{\circ} 35^{\prime} 26.0^{\prime \prime} \mathrm{W}\end{array}$ & --- & California Reef, Abrolhos & Soft bottom samples & \\
\hline I & $14^{\circ} 40^{\prime} \mathrm{S}, 145^{\circ} 26^{\prime} \mathrm{E}$ & $12-18 \mathrm{~m}$ & Lizard Island, Australia & $\begin{array}{l}\text { Coral rubble, nektonic } \\
\text { at night (no sampling } \\
\text { method info) }\end{array}$ & HugHes (2009) \\
\hline $\mathrm{J}$ & $\begin{array}{l}03^{\circ} 49^{\prime} 2.51^{\prime \prime} \mathrm{S} \\
32^{\circ} 23^{\prime} 34.10^{\prime \prime} \mathrm{W}\end{array}$ & $12 \mathrm{~m}$ & $\begin{array}{l}\text { Fernando de Noronha } \\
\text { Archipelago }\end{array}$ & $\begin{array}{l}\text { Rhodolith beds, SCUBA } \\
\text { Diving }\end{array}$ & Current study \\
\hline K & $\begin{array}{l}03^{\circ} 07^{\prime} 53.2^{\prime \prime} \mathrm{S} \\
38^{\circ} 49^{\prime} 26.2^{\prime \prime} \mathrm{W}\end{array}$ & $36 \mathrm{~m}$ & off Ceará State coast & $\begin{array}{l}\text { Van Veen grab, bottom of } \\
\text { gravel and sand spots }\end{array}$ & Current study \\
\hline $\mathrm{L}$ & $\begin{array}{c}08^{\circ} 08^{\prime} 06^{\prime \prime} \mathrm{S} \\
34^{\circ} 38^{\prime} 7.08^{\prime \prime} \mathrm{W}\end{array}$ & --- & off Pernambuco State coast & $\begin{array}{l}\text { Rectangular dredges, } \\
\text { bottom of bioclastic sand, } \\
\text { granules, and gravel }\end{array}$ & Current study \\
\hline$x^{1}$ & --- & --- & Tropical Atlantic & Pelagic & Bovallius (1886) \\
\hline $\mathrm{x}^{2}$ & --- & $0-50 \mathrm{~m}$ & Circumtropical & Epipelagic & BoLtovsKoy (1999) \\
\hline
\end{tabular}

distally, and two apical plumose setae. Additionally, the article 2 of the palp bears some short slender setae proximally. The specimens described by BARNARD \& THOMAs (1989) present three inner marginal and three apical plumose setae in this article. The material studied by Hughes (2009) has two inner marginal and two apical plumose setae. Finally, the specimens studied here present two variations: one inner marginal and two apical plumose setae (UERJ 542), or two inner marginal and three apical plumose setae (MOUFPE 19642), in both cases, inner margin of second article with a row of small slender setae.

While each material examined in this study and in other past works have a unique and different pattern of setae on the palp of mandible from the others, the shape variations of the lateral margins of telson can be grouped into only three morphotypes. Type 1 is the most common, with serrations at the distal quarter of the lateral margin, and it is present in populations from the Tropical Atlantic(off Ceará state coast, MOUFPE 19642; Bovallius, 1886), Madagascar
(LEDOYER, 1986), Florida Keys and Bahama (BARnARD \& Thomas, 1989), and Australia (Hughes, 2009). Type 2, with serrations at the distal half of the lateral margin, is observed in specimens from Bermuda (SHOEMAKER, 1945), Japan (HiraYAmA, 1988), and off Pernambuco state coast (MOUFPE 14566). Type 3 is the least common morphotype, with a smooth lateral margin, which a juvenile was recorded from Madagascar (LEDOYER, 1986) and herein, from Fernando de Noronha Archipelago (UERJ 542). First of all, we must bear in mind that we do not know what the holotype telson of this species looks like, since Dana has not described or illustrated it, and as has been said earlier, the type material is lost. It is noteworthy that just as the specimens described by Ledoyer have morphotypes 1 and 3, the latest being a juvenile, the material examined in this study from off northeastern Brazilian coast presents all three morphotypes. Additionally, the specimens from Ceará (MOUFPE 19642) and Pernambuco (MOUFPE 14566) show another variation in the telson, which is less cleft (about 50\%) than those of 
Fernando de Noronha (UERJ 542) and others previously described in the literature (about 70\%). It is possible, but not conclusive, that the morphological divergences between the different populations, especially in relation to the shape and ornamentation of telson, are the result of the growth stage of the specimens.

It is also interesting to note that specimens recorded from regions other than the Tropical Atlantic have unique character states, differentiating them from the different populations sampled between Africa and Brazil. By LEDOYER (1986), from Madagascar, coxa 3, posterior lobe is broadly rounded (versus subquadrate). By HiraYama (1988), from Japan, mandibular palp article 2 is subrectangular, about twice longer than wide (versus inflated, i.e. $1.6 \times$ longer than wide - MOUFPE 19642), and maxilla 2, the inner margin of inner plate is naked (versus densely setose). By BARNARD \& Thomas (1989), from Florida Keys, the inner margin of inner plate is strongly concave (versus almost straight). And Hughes (2009), from Australia, male accessory eyes have 3 ommatidia (versus 2 ommatidia) and in the pereopod 4 , the carpus is slender, about $2.5 \times$ longer than wide (versus inflated, about twice longer than wide).

The number and position of setae in each structure is always considered a subjective character as setae may be lost during fixation and handling of the material. Also, in some cases, we may simply be dealing with artifacts, from poor preparation, or mistaken observation of the material. On the other hand, a serrated/spinose or smooth margin is a state of character very commonly used by taxonomists to separate species. Even though it is a benthic species, most of the records of $S$. ultramarina mentioned here were made from plankton samplings with trawls, since it presents planktonic behavior at night, expanding its possibilities of dispersion. Although there is no data to indicate how far the specimens could disperse at night, this pelagic behavior could, in principle, favor gene flow and, thus, reduce morphological variability between populations. To date, with the data and specimens available, we cannot safely determine that all different populations, or even some of these, correspond to different species in a complex. Perhaps a future study using molecular data might shed light on whether we are really dealing with a cosmopolitan species or a complex of morphologically closely related species.

Acknowledgements. We thank the Fernando de Noronha Marine National Park for the license to survey and collect samples in the archipelago (SISBIO/34245-3). This study was financed in part by the Coordenação de Aperfeiçoamento de Pessoal de Nivel Superior - Brazil (CAPES) Finance Code 001 (fellowships to UNG and LFA). ARS is supported by PROCIENCIA (UERJ) and Fundação Carlos Chagas Filho de Amparo à Pesquisa do Estado do Rio de Janeiro (FAPERJ), grant process number E-26/202.768/2019.GHPF acknowledges the grant 2016/14017-0, Fundação de Amparo à Pesquisa do Estado de São Paulo (FAPESP) and the individual grant from the Conselho Nacional de Desenvolvimento Cientifico e Tecnológico (CNPq). Additional material was provided by Dr. Jesser F. Souza-Filho, from Museu de Oceanografia da Universidade Federal de Pernambuco (MOUFPE). Also, we would like to thank Dr. J. F. Souza-Filho and anonymous reviewers for the valuable comments and suggestions on this paper.

\section{REFERENCES}

BARNARD, J. L. 1969. The families and genera of marine gammaridean Amphipoda. Washington DC, Smithsonian Institution Press. 535p.

Barnard, J. L. 1972. A Review of the Family Synopiidae (=Tironidae), Mainly Distributed in the Deep Sea (Crustacea: Amphipoda). Smithsonian Contributions to Zoology 124:1-94.

Barnard, J. L. \& Thomas, J. D. 1989. Four species of Synopiidae from the Caribbean region (Crustacea: Amphipoda). Proceedings of the Biological Society of Washington 102(2):362-374.

Boltovskoy, D. 1999. South Atlantic Zooplankton. Vol. 1\&2. Leiden, Backhuys Publishers. 1706p.

Bovallius, C. 1886. Amphipoda Synopidea. Nova Acta Regiae Societatis Scientiarum Upsalaiensis, Series 3 13(9): 1-36.

Dana, J. D. 1853. Crustacea, Part II. In: United States Exploration Expedition. During the years 1838, 1839, 1840, 1841, 1842. Under the command of Charles Wilkes, U.S.N. Vol. 14. Philadelphia, Sherman, p. 689-1618.

GARM, A. \& WATLING, L. 2013. The Crustacean Integument: Setae, Setules, and Other Ornamentation. In: WatLing, T. \& Thiel, M. eds. The Natural History of the Crustacea. Functional Morphology and Diversity. Oxford, Oxford University Press, p. 167-198.

HiRAYAma, A. 1988. Taxonomic studies on the shallow water gammaridean Amphipoda of West Kyushu, Japan. VIII. Pleustidae, Podoceridae, Priscomilitaridae, Stenothoidae, Synopiidae and Urothoidae. Publications of the Seto Marine Biological Laboratory 33(1-3):39-77.

Horton, T.; Lowry, J.; De Broyer, C.; Bellan-Santini, D.; Coleman, C. O.; Corbari, L.; Costello, M. J.; Daneliya, M.; Dauvin, J.C.; Fišer, C.; Gasca, R.; Grabowski, M.; Guerra-García, J. M.; Hendrycks, E.; Hughes, L.; Jaume, D.; JaZdZewsKi, K.; Kim, Y.-H.; King, R.; KRAPP-SChICKel, T.; LeCroY, S.; LÖRZ, A.-N.; MAMOS, T.; Senna, A. R.; Serejo, C.; SKet, B.; Souza-Filho, J. F.; TANDberG, A. H.; Thomas, J. D.; Thurston, M.; Vader, W.; VÄInÖLÄ, R.; VonK, R.; White, K. \& Zeidler, W. 2020 onwards. World Amphipoda Database. Synopiidae Dana, 1853. Available at $<$ http://www. marinespecies.org/aphia.php? $\mathrm{p}=$ taxdetails $\&$ id $=101410>$. Accessed on 20 August 2019.

Hughes, L. E. 2009. Synopiidae. In: Lowry, J. K. \& Myers, A. A. eds. Benthic Amphipoda (Crustacea: Peracarida) of the Great Barrier Reef, Australia. Zootaxa 2260:880-891.

Ledoyer, M. 1986. CrustacésAmphipodesGammariens. FamillesdesHaustoriidaeà Vitjazianidae. Faune de Madagascar 59(2):599-1112.

Lörz, A. -N. \& Coleman, C. O. 2013. The Marine Fauna of New Zealand and the Ross Sea: Amphipoda, Synopiidae (Crustacea). Wellington, NIWA Biodiversity Memoir, 127. 160p.

Poore, A. G. B. \& Lowry, J. K. 1997. New ampithoid amphipods from Port Jackson, New South Wales, Australia (Crustacea: Amphipoda: Ampithoidae). Invertebrate Taxonomy 11:897-941.

RuFFo, S. 1993. The Amphipoda of the Mediterranean. Part 3. Gammaridea (Melphidippidae to Talitridae), Infolfiellidea, Caprellidea. Memoires de L'Institut Oceanographique Fondation Albert Ier, Prince De Monaco 13:577-813.

SChellenderg, A. 1926. Die Gammariden der DeutschenSüdpolarExpedition 1901-1903. Deutsche Südpolar-Expedition 18(Zoology 10):235-414 .

Serejo, C. S. \& Siqueira, S. G. L. 2018. Catalogue of the order Amphipoda from Brazil (Crustacea, Peracarida): suborders Amphilochidea, Senticaudata and order Ingolfiellida. Zootaxa 4431(1) 1-139.

Shoemaker, C. R. 1945. The Amphipoda of the Bermuda Oceanographic Expeditions, 1929-1931. Zoologica, Scientific Contributions to the New York Zoological Society 30:185-266.

Wakabara, Y.; Tararam, A. S.; Valério-Berardo, M. T.; Duleba, W. \& LeITE, F. P. P. 1991. Gammaridean and caprellidean fauna from Brazil. Hydrobiologia 223:69-77.

YounG, P. S. \& SEREJO, C. S. 2005. Crustacea of Abrolhos Region, Brazil. In: Dutra, G. F.; Allen, G. R.; Werner, T. \& McKenna, S. A. eds. A Rapid Marine Biodiversity Assessment of the Abrolhos Bank, Bahia, Brazil. RAP Bulletin of Biological Assessment 38. Washington, DC, Conservation International, p. 91-95. 